\title{
Erratum to: The Use of Individual Learning Styles in e-Learning
}

\author{
Y. Taratukhina, E. Sarapulova and E. Lavrenova
}

\section{Erratum to:}

Chapter 'The Use of Individual Learning Styles

in e-Learning' in: A. Kavoura et al. (eds.) Strategic

Innovative Marketing, Springer Proceedings in Business and Economics, DOI 10.1007/978-3-319-33865-1_71

In the original version of the book, in Chapter 'The Use of Individual Learning Styles in e-Learning', incorrect author names "Y. Taratukhina and Sarapulova E. Lavrenova" have to be changed as "Y. Taratukhina, E. Sarapulova, E. Lavrenova" and affiliation of author "E. Sarapulova" has to be updated. The erratum chapter and the book have been updated with the changes.

The updated online version of this chapter can be found at http://dx.doi.org/10.1007/978-3-319-33865-1_71 